\title{
Impact of Common Treatments Given in the Perinatal Period on the Developing Brain
}

\author{
Géraldine Favrais $^{\mathrm{a}} \quad$ Pierre Tourneux $^{\mathrm{b}} \quad$ Emmanuel Lopez $^{\mathrm{a}} \quad$ Xavier Durrmeyer $^{\mathrm{c}}$ \\ Géraldine Gascoin $^{d}$ Duksha Ramful ${ }^{\mathrm{e}}$ Elodie Zana-Taieb ${ }^{f}$ Olivier Baud ${ }^{g}$

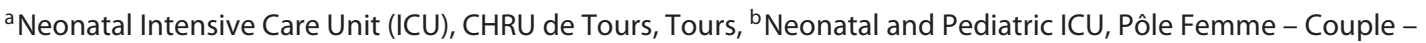 \\ Enfant, Amiens, ' Neonatal ICU and Clinical Research Centre, Centre Hospitalier Intercommunal de Créteil, Créteil, \\ d Neonatal ICU, University Hospital of Angers, Angers, eNeonatal and Pediatric ICU, CHR Félix Guyon, Saint-Denis, \\ La Réunion, ${ }^{\mathrm{f}}$ Neonatal ICU Port-Royal, Groupe Hospitalier Cochin-Broca-Hôtel Dieu, APHP, and ${ }^{9}$ Neonatal ICU, \\ Groupe Hospitalier Robert Debré, APHP, Paris, France
}

\section{Key Words}

Neuroprotection · Neonate $\cdot$ White-matter damage

\begin{abstract}
Background: Over the last decades, considerable progress has been made in the perinatal management of high-risk preterm neonates, changing the landscape of pathological conditions associated with neurological impairments. Major focal destructive lesions are now less common, and the predominant neuropathological lesion is diffuse white-matter damage in the most immature infants. Similarly, over the last few years, we have observed a trend towards a decrease in neurological impairment in the absence of treatments specifically aimed at neuroprotection. Objectives: We examined whether recent changes in treatment strategies in perinatal care during the perinatal period could have had an indirect beneficial impact on the occurrence of brain lesions and their consequences. Methods: Thus, we reviewed the effects of the most common treatments administered during the perinatal period to the mother or to very preterm infants on brain damage and neurocognitive follow-up. Results: Ante-
\end{abstract}

\section{KARGER}

E-Mail karger@karger.com

www.karger.com/neo natal steroids and exogenous surfactant are the two main treatments capable of leading to neuroprotection in very preterm infants. Randomized controlled trials are currently investigating the effects of inhaled nitric oxide and erythropoietin, while antenatal magnesium sulphate and caffeine are also likely to provide some neuroprotection, but this needs to be further investigated. Finally, other common treatments against pain, haemodynamic failure and patent ductus arteriosus have conflicting or no effects on the developing brain. Conclusion: While specific neuroprotective drugs are still awaited, recent advances in perinatal care have been associated with an unexpected but significant decrease in the incidence of both severe brain lesions and neurological impairment.

(c) 2014 S. Karger AG, Basel

\section{Introduction}

Brain injury and neurodevelopmental disabilities resulting from premature birth are a major public health concern. In recent studies, $5-10 \%$ of very preterm infants
(C) 2014 S. Karger AG, Basel

$1661-7800 / 14 / 1063-0163 \$ 39.50 / 0$
Olivier Baud, $\mathrm{MD}, \mathrm{PhD}$

Neonatal Intensive Care Unit and INSERM U1141

Hôpital Robert Debré, 48 blvd Sérurier

FR-75019 Paris (France)

E-Mail olivier.baud@ rdb.aphp.fr 
Table 1. Unexpected effects of perinatal drugs used in preterm infants: rationale in perinatal risk factors, preclinical and clinical evidences as well as long-term effects

\begin{tabular}{|c|c|c|c|c|}
\hline Risk factors & Drugs & $\begin{array}{l}\text { Preclinical evidence } \\
\text { for neuroprotection }\end{array}$ & $\begin{array}{l}\text { Beneficial effect } \\
\text { on brain lesions }\end{array}$ & $\begin{array}{l}\text { Long-term } \\
\text { effect }\end{array}$ \\
\hline Inflammation & $\begin{array}{l}\text { antibiotics } \\
\text { NSAIDs } \\
\text { antenatal steroids }\end{array}$ & $\begin{array}{l}0 \\
+ \\
++\end{array}$ & $\begin{array}{l}0 \\
+ \\
++\end{array}$ & $\begin{array}{l}0 \\
0 \\
+/-\end{array}$ \\
\hline $\begin{array}{l}\text { Hypoxia/haemodynamic } \\
\text { disturbances }\end{array}$ & $\begin{array}{l}\text { surfactant } \\
\text { caffeine } \\
\text { iNO } \\
\text { inotropes }\end{array}$ & $\begin{array}{l}? \\
++ \\
+ \\
0\end{array}$ & $\begin{array}{l}++ \\
+ \\
+/- \\
0\end{array}$ & $\begin{array}{l}+ \\
++ \\
+/- \\
0\end{array}$ \\
\hline Stress (pain) & opioids & $+/-$ & $+/-$ & 0 \\
\hline Growth factor deprivation & erythropoietin & +++ & + & + \\
\hline Excitotoxicity & magnesium sulphate & +++ & + & + \\
\hline
\end{tabular}

developed cerebral palsy (CP) and $25-50 \%$ had cognitive impairments and behavioural disorders. Neocortical white-matter damage (WMD) is strongly associated with these disabilities [1]. Over the last three decades, considerable progress has been made in the perinatal management of high-risk preterm neonates, changing the landscape of pathological conditions associated with neurological impairments. Major focal destructive lesions are now less common, and the most common neuropathological lesions are diffuse WMD [2]. Consistent with this evolution, subtle reductions in the incidence of neurological impairments have been reported in populationbased studies: in the EPICure 2 study, a higher proportion of babies admitted for neonatal care survived without disability in 2006 compared to those born in 1995 [3]. In the EXPRESS study, a high proportion (73\%) of extremely preterm infants had no or only mild disability at 2.5 years of age, but no comparisons were provided in this study [4]. Although CP and other neurobehavioural disabilities are considered multifactorial, we investigated whether recent improvements in perinatal care and changes in pharmacological strategies during the perinatal period could have an indirect beneficial impact on the occurrence and consequences of brain lesions. This review systematically examines the most common pharmacological treatments administered during the perinatal period to very preterm infants for such an effect. Five categories of treatment were considered according to the perinatal mechanism leading to brain damage and are summarized in table 1 .

\section{Antenatal Steroids}

The benefits of antenatal steroids (AS) administered to fetuses at risk of preterm delivery greatly outweigh the potential risks. Therefore, a single course of AS is routinely considered for preterm deliveries with a few exceptions. In the most recent meta-analysis of 21 studies (3,885 women and 4,269 infants) [5], in addition to its effect on respiratory distress syndrome (RDS), treatment with AS was associated with an overall reduction in cerebroventricular or intraventricular haemorrhage (IVH) [relative risk (RR) 0.54; 95\% confidence interval (CI) $0.43-0.69$ ] and severe IVH (RR 0.28; 95\% CI 0.16-0.50). Antenatal exposure to betamethasone but not dexamethasone was reported to be associated with a decreased risk of cystic periventricular leucomalacia among very premature infants in a retrospective study [6]. In addition, necrotizing enterocolitis (RR 0.46; 95\% CI 0.29-0.74) and systemic infections in the first $48 \mathrm{~h}$ of life (RR 0.56; $95 \%$ CI 0.38-0.85), two identified risk factors for brain lesions in preterm infants, were less frequently found in neonates born to mothers treated with AS. However, there is no evidence from this overview of a difference in the later incidence of CP between infants exposed to either antenatal betamethasone or dexamethasone.

Treatment with AS was associated with fewer developmental delays in childhood (RR 0.49; 95\% CI 0.24-1.00). However, in adulthood, statistically significant differences have been no longer noted in terms of educational level, visual, hearing or intellectual impairment [5]. 
The association between AS and potential neuroprotection appears to be primarily due to the well-known link between severe RDS and IVH, but it is also possible that AS could enhance the maturity of intracerebral vessels and thus provide protection against IVH.

Overall, these data support the view that AS, through indirect pathways, could be capable of exerting a positive effect on the developing brain in very preterm infants.

\section{Magnesium Sulphate}

Magnesium sulphate $\left(\mathrm{MgSO}_{4}\right)$ is used as a maternal neuroprotective agent to prevent eclampsia in women with pre-eclampsia and as an anticonvulsant for the treatment of eclampsia. Several observational studies reported a variable reduction in the risk of $\mathrm{CP}$, brain lesions or perinatal morbidity in preterm infants [7]. Four randomized controlled trials (RCTs) studying the use of antenatal $\mathrm{MgSO}_{4}$ administration to mothers at risk of preterm delivery for fetal neuroprotection have been conducted [811]. While none of these 4 trials individually has reported any statistical differences in the rates of their primary composite outcome (death/CP), secondary analyses demonstrated a reduction in the rate of neonatal CP among infants exposed to $\mathrm{MgSO}_{4}$. The Doyle Cochrane metaanalysis included a fifth trial aimed at comparing $\mathrm{MgSO}_{4}$ with placebo in women with pre-eclampsia [12] and demonstrated a significant reduction in CP in infants exposed to antenatal $\mathrm{MgSO}_{4}$ (RR 0.68; 95\% CI 0.54-0.87), confirmed within the neuroprotective-intent subgroup (RR 0.71 ; $95 \%$ CI $0.55-0.91$ ). In addition, substantial gross motor dysfunction, measured in four trials, was lower (RR 0.61; 95\% CI 0.44-0.85), and there was a significant reduction in the combined rate of death and $\mathrm{CP}$ in the neuroprotective-intent groups (RR 0.85 ; $95 \%$ CI $0.74-$ $0.98)$. Two other meta-analyses have come to similar conclusions $[13,14]$. However, a recent sequential trial analysis based on the Doyle Cochrane meta-analysis has revealed that the apparently conclusive positive effect may in fact be a false positive due to a random-risk error; thus, more data may be needed to confirm these associations [15].

The fetal neuroprotective mechanisms of $\mathrm{MgSO}_{4}$ have been partially elucidated through animal models, summarized in a review by Marret et al. [7]. Biological plausibility for the neuroprotective role of $\mathrm{MgSO}_{4}$ comes from its reduction of inflammation and free radicals accumulation, its prevention of excitotoxic injury and its stabilization of blood pressure (BP).

Neonatal Treatments and the Developing Brain
The Cochrane review has concluded on the proven cost-effectiveness and feasibility of $\mathrm{MgSO}_{4}$ therapy in preterm babies $<32$ weeks' gestational age (GA) $[16,17]$. However, the adoption of this strategy has been slow because the clinical evidence is still very controversial; in particular, unresolved issues concerning the optimal regimen of $\mathrm{MgSO}_{4}$ and the optimal GA at which the therapy is beneficial [18]. Nevertheless, the American College of Obstetricians and Gynecologists (March 2010), the Australian Research Centre for the Health of Women and Babies (March 2010) and the Society of Obstetricians and Gynaecologists of Canada (May 2011) have already published guidelines recommending that antenatal $\mathrm{MgSO}_{4}$ administration should be considered for fetal neuroprotection.

\section{Modulators of Inflammation/Infection}

Many experimental and epidemiological studies support the view that inflammatory/infectious processes such as chorioamnionitis and postnatal sepsis are associated with WMD and poorer neurological outcome [19]. In preterm infants, drugs with anti-inflammatory or antiinfectious effects are commonly used. It is therefore a valid question to ask whether these drugs could interact with brain development.

\section{Non-Steroidal Anti-Inflammatory Drugs}

The current recommended indication for non-steroidal anti-inflammatory drugs (NSAIDs) in the preterm neonatal period is the curative medical treatment of persistent ductus arteriosus [20]. Experimental data indicate that NSAIDs could be neuroprotective in the developing brain in the context of systemic inflammation, through a reduction in brain prostaglandin $\mathrm{E}_{2}$ synthesis by cyclooxygenase- 2 inhibition at the blood-brain barrier [21].

Several years ago, early indomethacin was thought to be neuroprotective against the risk of IVH in preterm infants with a significant decrease in severe IVH [22-24]. However, the long-term effects on neurodevelopmental outcome were less convincing, with a lack of improved neurological outcome [25-28]. Currently, the use of indomethacin as a preventive strategy for IVH is not clearly recommended, although a prospective analysis of factors influencing white-matter abnormalities on MRI scans in extremely low GA infants has revealed a significant beneficial effect of indomethacin [29]. Unlike indomethacin, however, ibuprofen did not show any effect on the occurrence of IVH $[30,31]$. 


\section{Antibiotics}

During pregnancy, antibiotics and AS are currently considered the standard of care in preterm prelabour rupture of membranes (pPROM) occurring before 32 weeks' GA even without proven infection. However, no consensus exists regarding the antibiotic to be used, apart from the avoidance of the amoxicillin-clavulanic acid combination due to the increased risk of necrotizing enterocolitis associated with it [32]. In case of pPROM, antibiotics reduce neonatal infections, surfactant use and oxygen requirement [33]. In contrast, no positive effect of antibiotics has been observed on neonatal death or morbidity in preterm labour with intact membranes [34].

Some antibiotics have demonstrated neuroprotective actions in animal models not through their bactericidal effects but through their anti-inflammatory properties (minocycline and fluoroquinolone) or anti-excitotoxic properties (ceftriaxone) [35-37]. While these findings are very encouraging, the potential of these antibiotics remains fairly limited due to their possible adverse effects in neonates.

Focusing on neurological outcome, clinical data are only available for antibiotics used in the antenatal period. Antibiotic use in the context of pPROM was associated with a significant reduction in IVH (RR 0.67; 95\% CI 0.49-0.91) and in abnormal cerebral ultrasound results prior to discharge (RR $0.81 ; 95 \%$ CI 0.68-0.98) [32]. The ORACLE I study was designed as a long-term follow-up of infants receiving prenatal antibiotics for pPROM and reported no demonstrable effect on neurological outcome compared to the absence of treatment [38]. In parallel, the same study design (ORACLE II) was adopted for a follow-up of prenatal antibiotics for preterm labour with intact membranes [39]. Surprisingly, prenatal exposure to antibiotics in this case was associated with an increased occurrence of CP at 7 years [odds ratio (OR) 1.93; 95\% CI 1.21-3.09 for erythromycin]. The most recent review assessing the effects of prophylactic antibiotics administered to women in preterm labour with intact membranes reported that a marginally non-statistically significant (but of concern) increase was shown in any functional impairment and CP in any antibiotics groups versus placebo [40]. Thus, antenatal antibiotics only show short-term beneficial effects limited to the context of pPROM. In contrast, the evidence supports not giving antibiotics routinely to women in preterm labour with intact membranes in the absence of overt signs of infection.

\section{Exogenous Surfactant}

Surfactant therapy is one of the few treatments that decreases overall mortality in preterm newborns with RDS and has significantly changed clinical practice in neonatology that could strongly influence their neurodevelopmental prognosis [41].

\section{Exogenous Surfactant and Changes in Cerebral Blood}

Flow Velocity

Early physiological studies indicated that surfactant administration produced a rapid improvement in ventilation associated with a transient and rapid change in cerebral blood flow velocity (CBFV), strongly correlated with an increase in carbon dioxide tension [42-44]. However, later clinical data have not revealed any change in CBFV following natural surfactant instillation [45]. From these results, a close monitoring of blood gases and a frequent adjustment of ventilation have been proposed to prevent potential neurological side effects caused by CBFV changes related to surfactant administration.

\section{Exogenous Surfactant and IVH}

In the early 1990s, a multicentre controlled study using beractant was stopped before enrolment was completed when an increased incidence of periventricular haemorrhage/IVH was reported in treated infants [46]. However, a review of a database including 17 studies and almost 1,700 infants did not confirm these results [47]. A recent Cochrane database analysis comparing the prophylactic and selective use of surfactant in newborns with RDS has revealed a borderline benefit of the prophylactic use in preventing IVH (RR 0.91; 95\% CI 0.82-1.00) [48]. No difference in the risk of periventricular leucomalacia was observed between the two groups (RR 1.23;95\% CI 0.75-2.01).

\section{Exogenous Surfactant and Neurological Outcome}

A meta-analysis including 13 RCTs comparing surfactant treatment (prophylactic or rescue treatment: 2,218 infants) versus controls (2,090 infants) revealed that surfactant therapy was associated with a lower rate of mild disability at 1 year of age (OR 0.79 ; 95\% CI $0.66-0.95$ ) [49]. As previously reported, many factors interfere with long-term follow-up, and the effect was no longer observed in studies evaluating the infants at 2 years of age and at schoolgoing age, either in terms of neurological disabilities, IQ tests, learning problems, behavioural problems, or hyperactivity [50].

In summary, surfactant therapy has changed clinical practice in neonatology over the last decades, resulting
Favrais/Tourneux/Lopez/Durrmeyer/ Gascoin/Ramful/Zana-Taieb/Baud 
in an overall reduction in infant mortality of about $6 \%$ in the United States [51]. Long-term follow-up studies have not identified any increase of decrease in neurodevelopmental sequelae in surviving infants above 2 years of age.

\section{Caffeine}

Caffeine is a methylxanthine and a non-selective adenosine antagonist widely used in preterm infants to prevent apnoea of prematurity. The nucleoside adenosine may play an important role as a mediator of hypoxic injury in preclinical models of developing brain injury. When rodents are treated with adenosine receptor agonists, there is a marked reduction in white- and grey-matter volumes along with secondary ventriculomegaly and reduced myelination, similar to that seen in rodents exposed to hypoxia [52] or with diffuse periventricular leucomalacia [53]. Compounds that block the activation of adenosine receptors include caffeine, of which the potential role in the prevention of developmental brain injury has been poorly explored.

Back et al. [54] have reported that caffeine enhances oligodendroglial maturation in a neonatal model of diffuse white-matter injury and reduces ventriculomegaly. Caffeine could potentiate neural plasticity, modulate synaptic activity and modify neural networks.

Recently, clinical studies have supported the view that caffeine has beneficial effects in preterm babies, and not only to treat apnoea of prematurity. In the Caffeine for Apnea of Prematurity (CAP) trial, exposure to caffeine was associated with reduced rates of bronchopulmonary dysplasia and patent ductus arteriosus [55]. The frequency and types of brain injury determined by cranial ultrasound were similar between patient groups. Brain ultrastructure demonstrated that caffeine treatment was associated with a decreased apparent diffusion coefficient and a more mature cerebral white-matter organization at term-equivalent age [56]. At 18-21 months of age, caffeine-treated infants had significantly lower rates of CP (4.4 vs. $7.3 \%$ ) and cognitive delays (33.8 vs. $38.3 \%$ ) than the control group [57]. However, at 5 years of age, the observed rates of the combined main outcome of death/disability revealed no effect of caffeine compared to placebo treatment [58]. Secondary analysis suggested that the improved motor function observed at 18-21 months of age in the caffeine group was sustained at 5 years, together with better scores in the coordination and visual perception fields. A dose-response trial revealed a significant statistical improvement of general quotient development as assessed by the Griffiths Mental Development Scales in the high-dose group (GQ 98.0 vs. 93.6) [59].

\section{Inhaled Nitric Oxide}

Nitric oxide (NO) is a powerful vasodilator that plays a crucial role in vasodilating pulmonary arterioles. $\mathrm{NO}$ is also involved in the pathogenesis of several conditions, including brain ischaemia and neurodegenerative diseases [60]. Importantly, $\mathrm{NO}$ appears to be a key regulator of cerebral blood flow and inflammation, two major factors modulating brain injury. Surprisingly, despite its potential impact, neurological surveys of preterm infants exposed to inhaled NO (iNO) are rare and poorly reported. In a recent meta-analysis, Donohue et al. [61] reviewed 14 RCTs of preterm infants exposed to iNO for severe persistent pulmonary hypertension, including 7 followup studies and 1 observational study. Mortality rates in the NICU did not differ for infants treated with iNO compared with controls, and there was no evidence to suggest a difference in the incidence of CP (RR 1.36; 95\% CI 0.882.10), neurodevelopmental impairment (RR 0.91; 95\% CI $0.77-1.12$ ) or cognitive impairment (RR $0.72 ; 95 \%$ CI $0.35-1.45)$.

Nevertheless, the neurodevelopmental effects of iNO continue to be investigated. Indeed, exogenous iNO under experimental conditions is capable of exerting both beneficial and detrimental effects in the developing brain, depending on its concentration and the time period of exposure [62]. Consistent with this, preclinical data in animal models of the brain damage observed in preterm and term neonates and adults suggest that at low doses, iNO could decrease the oxidative burst frequently observed in the perinatal period by scavenging oxygen-derived free radicals [63].

In the past, it was feared that iNO would increase the incidence of intracranial haemorrhage in critically ill preterm neonates, because NO is known to increase bleeding time and inhibit platelet aggregation [64]. However, later clinical studies have shown that there is no significant increase in intracranial bleeding in preterm neonates. Moreover, both Schreiber et al. [65] and Kinsella et al. [66] have noted a lower incidence of severe IVH and periventricular leucomalacia in iNO-treated preterm infants, and another recent report reveals beneficial effects of iNO on long-term neurological outcomes in premature infants [67]. However, this has not been confirmed in 3 large multicentre RCTs. 
Table 2. rhEpo for neuroprotection in preterm infants

\begin{tabular}{|c|c|c|c|c|c|c|c|c|}
\hline Studies & Year & $\mathrm{n}$ & $\begin{array}{l}\text { Inclusion } \\
\text { criteria }\end{array}$ & rhEpo dose & \multicolumn{3}{|l|}{ Neurodevelopmental outcome } & $\mathrm{p}$ \\
\hline Newton & 1999 & 40 & $\leq 1,250 \mathrm{~g}$ & 500 or $1,000 \mathrm{U} / \mathrm{kg} /$ week & MDI at 17 months & $95.4 \pm 9.9$ & $94.6 \pm 18.7$ & NS \\
\hline Ohls & 2001 & 102 & $\leq 1,000 \mathrm{~g}$ & $1,200 \mathrm{U} / \mathrm{kg} /$ week & $\begin{array}{l}\% \mathrm{MDI}<70 \text { at } 18-22 \text { months } \\
\% \mathrm{PDI}<70 \text { at } 18-22 \text { months } \\
\% \mathrm{CP} \text { at } 18-22 \text { months }\end{array}$ & $\begin{array}{l}31 \% \\
31 \% \\
19 \%\end{array}$ & $\begin{array}{l}36 \% \\
13 \% \\
18 \%\end{array}$ & $\begin{array}{c}\text { NS } \\
<0.05 \\
\text { NS }\end{array}$ \\
\hline Neubauer & 2010 & 146 & $<1,000 \mathrm{~g}$ & 750 or $1,500 \mathrm{U} / \mathrm{kg} /$ week & $\begin{array}{l}\text { IQ score at } 10-13 \text { years } \\
\text { normal development }\end{array}$ & $\begin{array}{l}90.8 \pm 17.2 \\
55 \%\end{array}$ & $\begin{array}{l}81.3 \pm 21.1 \\
39 \%\end{array}$ & $\begin{array}{l}<0.005 \\
<0.05\end{array}$ \\
\hline McAdams & 2013 & 35 & $<1,000 \mathrm{~g}$ & $\begin{array}{l}500,1,000 \text { or } 2,500 \mathrm{U} / \mathrm{kg} \\
(3 \text { doses })\end{array}$ & $\begin{array}{l}\text { cognitive score from } 4 \text { to } 36 \text { months } \\
\text { motor score from } 4 \text { to } 36 \text { months }\end{array}$ & $\begin{array}{l}\Delta \text { score }=5.3 \\
\Delta \text { score }=7.5\end{array}$ & & $\begin{array}{l}0.044 \\
0.026\end{array}$ \\
\hline
\end{tabular}

MDI = Mental development index; PDI = physical development index; IQ = intelligence quotient; NS = non-significant. * Epo concentrations: $\geq 500<500$ $\mathrm{mU} / \mathrm{ml}$.

\section{Recombinant Human Erythropoietin}

Apart from its well-known haematopoietic effects, erythropoietin (Epo) and its receptor (EpoR) are widely expressed in central nervous system cells and play a key role in brain development. Epo has been shown to have neurotrophic and neuroprotective effects in a wide variety of experimental paradigms [68]. Several mechanisms by which Epo results in neuroprotection have been recognized. Epo decreases glutamate toxicity, induces the generation of neuronal anti-apoptotic factors, reduces inflammation, decreases NO-mediated injury, and has direct antioxidant effects.

Little information is known about the neurological impact of Epo in preterm infants. Two studies reported no significant influence of a haematopoietic dose of recombinant human Epo (rhEpo) on the neurocognitive outcome of very preterm infants at $18-22$ months of age $[69,70]$. Bierer et al. [71] were the first to report that infants with elevated Epo concentrations had higher Mental Development Index scores at a corrected age of 18-22 months in a small cohort of extremely low birth weight (ELBW) infants. In a non-randomized study, Neubauer et al. [72] reported that rhEpo-treated infants had better developmental outcomes (55 vs. 39\% with normal development, $\mathrm{p}<0.05)$ and composite IQ scores $(90.8$ vs. $81.3, \mathrm{p}<0.005)$ between the ages of 10 and 13 years com- pared to the placebo group. The neuroprotective effect of rhEpo treatment was more significant in preterm infants with IVH. Table 2 summarizes the results of studies using haematopoietic doses of Epo in preterm infants.

Conversely, a pilot study in 45 very preterm infants showed no difference in terms of either survival without brain injury or retinopathy ( 53 vs. $60 \%$, OR 0.76 ; $95 \%$ CI 0.24-3.20) or of short-term outcome in rhEpo-treated infants compared to placebo-treated controls [73]. In ELBW infants, an early high dose of rhEpo was well tolerated with no increase in morbidity or mortality, and was correlated with a modest improvement in neurodevelopmental outcome up to 36 months' postmenstrual age [74, 75]. Multicentre trials enrolling ELBW infants are ongoing or being planned. The completion of recruitment and primary outcome measurements are expected for 2014 and 2018 (table 2). In addition to rhEpo treatment, iron supplementation and subsequent serum ferritin levels may have a positive impact on motor performances at 24 months of age [76].

In conclusion, only 1 study has demonstrated a neuroprotective effect of rhEpo treatment at haematopoietic doses, but these results should be interpreted with caution until the results of high-dose rhEpo trials are reported. 


\section{Treatment of Haemodynamic Failure}

Systemic hypotension in preterm infants has been correlated with increased mortality, cerebrovascular lesions and neurodevelopmental morbidity. The 3 meta-analyses available in the Cochrane Library that compared the effectiveness of early volume expansion and inotropes in increasing BP in preterm infants drew conflicting conclusions [77-79]. None of them demonstrated any significant difference in neonatal mortality at discharge, the incidence of cerebrovascular lesions or CP. Nevertheless, in 1 randomized trial, surviving infants treated with dobutamine had a significantly higher general quotient when evaluated using the Griffiths Mental Development Scales at 3 years [80].

A more recent random-effects meta-analysis compared various strategies to sustain BP in preterm infants, including inotropes, volume expansion and hydrocortisone [81]. Dopamine administration was significantly more effective at sustaining BP than dobutamine, colloid, or hydrocortisone. Despite increased cerebral blood flow in dopamine-treated neonates, there were no statistically significant differences in adverse neurological outcome between dopamine and dobutamine, epinephrine, colloid or hydrocortisone administration. A recent study has investigated the relationship between BP, inotrope therapy and in-hospital outcomes to identify a BP threshold below which antihypotensive therapies could be beneficial [82]. For the 15 definitions of low BP investigated, no therapy was prescribed to 3-49\% of infants, but paradoxically, therapy was administered to $28-41 \%$ of infants without low BP, suggesting that factors other than low BP contribute to the decision to use antihypotensive therapies. Despite an increased incidence of severe IVH in treated infants (22 vs. $11 \%, \mathrm{p}<$ 0.01 ), this difference did not persist after regression analysis.

In conclusion, there is no evidence that the treatment of systemic hypotension with a specific molecule could result in short- or long-term improvements of neurological outcome, and outcomes were not improved with antihypotensive therapy whatever the definition of low BP used $[82,83]$.

\section{Pain, Analgesia and Sedation}

A major issue of concern to neonatologists is the potential delayed toxicity of the perinatal environment, interventions and drugs. Except in preterm infants under- going surgery [84], whether systematic analgesia or sedation in the NICU results in improved short-term outcome is a matter of debate $[85,86]$.

Animal experiments have revealed a variety of effects of most analgesics, sedatives and anaesthetics, depending on the species, exposure conditions and experimental design [87]. Pain itself can also cause long-term behavioural changes in animals [88]. Extrapolations of these results to humans should be carried out with caution, considering differences in pharmacokinetics, the equivalence of developmental stages, nutritional support, and nociceptive stimuli between most models [89].

To date, no prospective clinical trial has used longterm neurodevelopmental outcome as a primary outcome for the assessment of pain management. Even sucrose analgesia, which is extremely widespread and effective for minor procedures, has never been assessed for its long-term outcome [90], although one study reported no change in short-term outcomes [91]. On the other hand, despite the need for large trials of analgesics and/or sedatives designed to assess long-term neurodevelopment as the primary outcome, these would be considered ethically unacceptable in light of the short-term effectiveness in providing pain relief of most of these drugs.

Based on the existing evidence, 4 studies have analyzed the relationship between exposure to neonatal analgesic/ sedative drugs and outcome at schoolgoing age [92-95]. None of these trials were designed to assess long-term outcomes. Surprisingly, the 2 largest trials of morphine versus placebo in ventilated neonates have yielded contradictory results concerning severe brain injury: Simons et al. [96] noted a protective effect of morphine on all grades of IVH, while Anand et al. [97] saw an increase in severe IVH in a subgroup of infants.

An observational study has reported an association between painful experience and poor neurodevelopmental outcome at 18 months [97]. Conversely, no difference was observed between the groups in a 5-year follow-up of Simons et al.'s [96] study. In the NEOPAIN study, impairment in neurodevelopmental subtests were reported for the morphine group compared to the placebo group in one centre, which, however, recruited less than $10 \%$ of the patients [98]. Finally, a retrospective analysis of infants recruited in the EPIPAGE cohort using a propensity score to compare infants who had received analgesia/ sedation on at least 7 consecutive days with controls found no positive or negative effect of this treatment at 5 years [93]. 


\section{Conclusion}

Common practice in perinatal care has profoundly changed over the last three decades. Similarly, during the last few years, we have observed a significant decrease in the incidence of major brain lesions in preterm infants and a trend towards a decrease in neurological impairment. This review shows that, while specific neuroprotec- tive drugs are still awaited, recent advances and changes in perinatal care have been associated with unexpected but significant decreases in the incidence of both severe brain lesions and neurological impairment. The greatest benefits on the developing brain could result from an indirect positive impact of AS, an exogenous surfactant and possibly $\mathrm{MgSO}_{4}$ as well as caffeine.

\section{References}

1 Khwaja O, Volpe JJ: Pathogenesis of cerebral white matter injury of prematurity. Arch Dis Child Fetal Neonatal Ed 2008;93:F153-F161.

2 Kaindl AM, Favrais G, Gressens P: Molecular mechanisms involved in injury to the preterm brain. J Child Neurol 2009;24:1112-1118.

$\checkmark 3$ Moore T, Hennessy EM, Myles J, Johnson SJ, Draper ES, Costeloe KL, Marlow N: Neurological and developmental outcome in extremely preterm children born in England in 1995 and 2006: the EPICure studies. BMJ 2012;345:e7961.

-4 Serenius F, Källén K, Blennow M, Ewald U, Fellman V, Holmström G, Lindberg E, Lundqvist $\mathrm{P}$, Maršál K, Norman M, Olhager E, Stigson L, Stjernqvist K, Vollmer B, Strömberg B; EXPRESS Group: Neurodevelopmental outcome in extremely preterm infants at 2.5 years after active perinatal care in Sweden. JAMA 2013;309:1810-1820.

5 Roberts D, Dalziel S: Antenatal corticosteroids for accelerating fetal lung maturation for women at risk of preterm birth. Cochrane Database Syst Rev 2006;3:CD004454.

6 6 Baud O, Foix-L'Helias L, Kaminski M, Audibert F, Jarreau PH, Papiernik E, Huon C, Lepercq J, Dehan M, Lacaze-Masmonteil T: Antenatal glucocorticoid treatment and cystic periventricular leukomalacia in very premature infants. N Engl J Med 1999;341:11901196.

7 Marret S, Doyle LW, Crowther CA, Middleton P: Antenatal magnesium sulphate neuroprotection in the preterm infant. Semin Fetal Neonatal Med 2007;12:311-317.

8 Crowther CA, Hiller JE, Doyle LW, Haslam RR; Australasian Collaborative Trial of Magnesium Sulphate (ACTOMg SO4) Collaborative Group: Effect of magnesium sulfate given for neuroprotection before preterm birth: a randomized controlled trial. JAMA 2003;290: 2669-2676.

-9 Marret S, Marpeau L, Zupan-Simunek V, Eurin D, Lévêque C, Hellot MF, Bénichou J; PREMAG Trial Group: Magnesium sulphate given before very-preterm birth to protect infant brain: the randomised controlled PREMAG trial. BJOG 2007;114:310-318.
10 Mittendorf R, Dambrosia J, Pryde PG, Lee KS, Gianopoulos JG, Besinger RE, Tomich PG: Association between the use of antenatal magnesium sulfate in preterm labor and adverse health outcomes in infants. Am J Obstet Gynecol 2002;186:1111-1118.

11 Rouse DJ, Hirtz DG, Thom E, Varner MW, Spong CY, Mercer BM, Iams JD, Wapner RJ, Sorokin Y, Alexander JM, Harper M, Thorp JM Jr, Ramin SM, Malone FD, Carpenter M, Miodovnik M, Moawad A, O'Sullivan MJ, Peaceman AM, Hankins GD, Langer O, Caritis SN, Roberts JM; Eunice Kennedy Shriver NICHD Maternal-Fetal Medicine Units Network: A randomized, controlled trial of magnesium sulfate for the prevention of cerebral palsy. N Engl J Med 2008;359:895-905.

12 Magpie Trial Follow-Up Study Collaborative Group: The Magpie Trial: a randomised trial comparing magnesium sulphate with placebo for pre-eclampsia. Outcome for children at 18 months. BJOG 2007;114:289-299.

13 Conde-Agudelo A, Romero R: Antenatal magnesium sulfate for the prevention of cerebral palsy in preterm infants less than 34 weeks' gestation: a systematic review and meta-analysis. Am J Obstet Gynecol 2009;200: 595-609.

14 Costantine MM, Weiner SJ; Eunice Kennedy Shriver National Institute of Child Health and Human Development Maternal-Fetal Medicine Units Network: Effects of antenatal exposure to magnesium sulfate on neuroprotection and mortality in preterm infants: a metaanalysis. Obstet Gynecol 2009;114:354-364.

15 Brok J, Huusom LD, Thorlund K: Conclusive meta-analyses on antenatal magnesium may be inconclusive! Are we underestimating the risk of random error? Acta Obstet Gynecol Scand 2012;91:1247-1251.

16 Doyle LW, Crowther CA, Middleton P, Marret S, Rouse D: Magnesium sulphate for women at risk of preterm birth for neuroprotection of the fetus. Cochrane Database Syst Rev 2009; 1:CD004661.

17 Doyle LW: Antenatal magnesium sulfate and neuroprotection. Curr Opin Pediatr 2012;24: 154-159.
8 AMICABLE Group: Antenatal magnesium individual participant data international collaboration assessing the benefits for babies using the best level of evidence (AMICABLE). Syst Rev 2012;1:21.

19 Dammann O, Kuban KC, Leviton A: Perinatal infection, fetal inflammatory response, white matter damage, and cognitive limitations in children born preterm. Ment Retard Dev Disabil Res Rev 2002;8:46-50.

20 Ohlsson A, Walia R, Shah SS: Ibuprofen for the treatment of patent ductus arteriosus in preterm and/or low birth weight infants. Cochrane Database Syst Rev 2013;4:CD003481.

21 Favrais G, Schwendimann L, Gressens P, Lelièvre V: Cyclooxygenase-2 mediates the sensitizing effects of systemic IL- $1 \beta$ on excitotoxic brain lesions in newborn mice. Neurobiol Dis 2007;25:496-505.

22 Bandstra ES, Montalvo BM, Goldberg RN, Pacheco I, Ferrer PL, Flynn J, et al: Prophylactic indomethacin for prevention of intraventricular hemorrhage in premature infants. Pediatrics 1988;82:533-542.

23 Ment LR, Oh W, Ehrenkranz RA, Phillip AG, Vohr B, Allan W, Makuch RW, Taylor KJ, Schneider KC, Katz KH, et al: Low-dose indomethacin therapy and extension of intraventricular hemorrhage: a multicenter randomized trial. J Pediatr 1994;124:951-955.

24 Schmidt B, Davis P, Moddemann D, Ohlsson A, Roberts RS, Saigal S, Solimano A, Vincer M, Wright LL; Trial of Indomethacin Prophylaxis in Preterms Investigators: Long-term effects of indomethacin prophylaxis in extremely-low-birth-weight infants. N Engl J Med 2001;344:1966-1972.

25 Ment LR, Oh W, Ehrenkranz RA, Philip AG, Vohr B, Allan W, Duncan CC, Scott DT, Taylor KJ, Katz KH, et al: Low-dose indomethacin and prevention of intraventricular hemorrhage: a multicenter randomized trial. Pediatrics 1994;93:543-550.

26 Ment LR, Vohr B, Allan W, Westerveld M, Sparrow SS, Schneider KC, Katz KH, Duncan CC, Makuch RW: Outcome of children in the indomethacin intraventricular hemorrhage prevention trial. Pediatrics 2000;105:485491. 
-27 Ment LR, Vohr B, Oh W, Scott DT, Allan WC, Westerveld M, Duncan CC, Ehrenkranz RA, Katz KH, Schneider KC, Makuch RW: Neurodevelopmental outcome at 36 months' corrected age of preterm infants in the Multicenter Indomethacin Intraventricular Hemorrhage Prevention Trial. Pediatrics 1996;98: 714-718.

-28 Vohr BR, Allan WC, Westerveld M, Schneider KC, Katz KH, Makuch RW, Ment LR: School-age outcomes of very low birth weight infants in the indomethacin intraventricular hemorrhage prevention trial. Pediatrics 2003; 111:e340-e346.

-29 Miller SP, Mayer EE, Clyman RI, Glidden DV, Hamrick SEG, Barkovich AJ: Prolonged indomethacin exposure is associated with decreased white matter injury detected with magnetic resonance imaging in premature newborns at 24-28 weeks' gestation at birth. Pediatrics 2006;117:1626-1631.

- 30 Van Overmeire B, Allegaert K, Casaer A, Debauche C, Decaluwé W, Jespers A, Weyler J, Harrewijn I, Langhendries JP: Prophylactic ibuprofen in premature infants: a multicentre, randomised, double-blind, placebo-controlled trial. Lancet 2004;364:1945-1949.

- 31 Dani C, Bertini G, Pezzati M, Poggi C, Guerrini P, Martano C, Rubaltelli FF; IntraVentricular Ibuprofen Study Group: Prophylactic ibuprofen for the prevention of intraventricular hemorrhage among preterm infants: a multicenter, randomized study. Pediatrics 2005;115:1529-1535.

- 32 Kenyon SL, Taylor DJ, Tarnow-Mordi W; ORACLE Collaborative Group: Broad-spectrum antibiotics for preterm, prelabour rupture of fetal membranes: the ORACLE I randomised trial. ORACLE Collaborative Group. Lancet 2001;357:979-988.

-33 Kenyon S, Boulvain M, Neilson J: Antibiotics for preterm rupture of membranes. Cochrane Database Syst Rev 2003;2:CD001058.

- 34 Hutzal CE, Boyle EM, Kenyon SL, Nash JV, Winsor S, Taylor DJ, Kirpalani H: Use of antibiotics for the treatment of preterm parturition and prevention of neonatal morbidity: a meta-analysis. Am J Obstet Gynecol 2008; 199:620.e1-e8.

- 35 Fan LW, Pang Y, Lin S, Tien LT, Ma T, Rhodes PG, Cai Z: Minocycline reduces lipopolysaccharide-induced neurological dysfunction and brain injury in the neonatal rat. J Neurosci Res 2005;82:71-82.

- 36 Loron G, Olivier P, See H, Le Saché N, Angulo L, Biran V, Brunelle N, Besson-Lescure B, Kitzis MD, Pansiot J, Bingen E, Gressens P, Bonacorsi S, Baud O: Ciprofloxacin prevents myelination delay in neonatal rats subjected to E. coli sepsis. Ann Neurol 2011;69:341-351.

-37 Lipski J, Wan CK, Bai JZ, Pi R, Li D, Donnelly D: Neuroprotective potential of ceftriaxone in in vitro models of stroke. Neuroscience 2007;146:617-629.
Kenyon S, Pike K, Jones DR, Brocklehurst P, Marlow N, Salt A, Taylor DJ: Childhood outcomes after prescription of antibiotics to pregnant women with preterm rupture of the membranes: 7-year follow-up of the ORACLE I trial. Lancet 2008;372:1310-1318.

39 Kenyon S, Pike K, Jones DR, Brocklehurst P, Marlow N, Salt A, Taylor DJ: Childhood outcomes after prescription of antibiotics to pregnant women with spontaneous preterm labour: 7-year follow-up of the ORACLE II trial. Lancet 2008;372:1319-1327.

40 Flenady V, Hawley G, Stock OM, Kenyon S, Badawi N: Prophylactic antibiotics for inhibiting preterm labour with intact membranes. Cochrane Database Syst Rev 2013;12: CD000246.

41 Soll R, Ozek E: Prophylactic protein free synthetic surfactant for preventing morbidity and mortality in preterm infants. Cochrane Database Syst Rev 2010;1:CD001079.

42 Saliba E, Nashashibi M, Vaillant MC, Nasr C, Laugier J: Instillation rate effects of Exosurf on cerebral and cardiovascular haemodynamics in preterm neonates. Arch Dis Child Fetal Neonatal Ed 1994;71:F174-F178.

-43 Murdoch E, Kempley ST: Randomized trial examining cerebral haemodynamics following artificial or animal surfactant. Acta Paediatr 1998;87:411-415.

-44 Kaiser JR, Gauss CH, Williams DK: Surfactant administration acutely affects cerebral and systemic hemodynamics and gas exchange in very-low-birth-weight infants. J Pediatr 2004;144:809-814.

45 Nuntnarumit P, Bada HS, Yang W, Korones SB: Cerebral blood flow velocity changes after bovine natural surfactant instillation. J Perinatol 2000;20:240-243.

46 Horbar JD, Soll RF, Schachinger H, Kewitz G, Versmold HT, Lindner W, Duc G, Mieth D, Linderkamp O, Zilow EP, et al: A European multicenter randomized controlled trial of single dose surfactant therapy for idiopathic respiratory distress syndrome. Eur J Pediatr 1990;149:416-423.

47 Gunkel JH, Banks PL: Surfactant therapy and intracranial hemorrhage: review of the literature and results of new analyses. Pediatrics 1993;92:775-786.

48 Rojas-Reyes MX, Morley CJ, Soll R: Prophylactic versus selective use of surfactant in preventing morbidity and mortality in preterm infants. Cochrane Database Syst Rev 2012;3: CD000510.

49 Sinn JK, Ward MC, Henderson-Smart DJ: Developmental outcome of preterm infants after surfactant therapy: systematic review of randomized controlled trials. J Paediatr Child Health 2002;38:597-600.

50 Sinkin RA, Kramer BM, Merzbach JL, Myers GJ, Brooks JG, Palumbo DR, Cox C, Kendig JW, Mercier CE, Phelps DL: School-age follow-up of prophylactic versus rescue surfactant trial: pulmonary, neurodevelopmental, and educational outcomes. Pediatrics 1998; 101:E11.
51 Halliday HL: Surfactants: past, present and future. J Perinatol 2008;28:S47-S56.

-52 Turner CP, Seli M, Ment L, Stewart W, Yan H, Johansson B, Fredholm BB, Blackburn M, Rivkees SA: A1 adenosine receptors mediate hypoxia-induced ventriculomegaly. Proc Natl Acad Sci USA 2003;100:11718-11722.

53 Back SA, Rivkees SA: Emerging concepts in periventricular white matter injury. Semin Perinatol 2004;28:405-414.

54 Back SA, Craig A, Luo NL, Ren J, Akundi RS, Ribeiro I, Rivkees SA: Protective effects of caffeine on chronic hypoxia-induced perinatal white-matter injury. Ann Neurol 2006;60: 696-705.

55 Schmidt B, Roberts RS, Davis P, Doyle LW, Barrington KJ, Ohlsson A, Solimano A, Tin W; Caffeine for Apnea of Prematurity Trial Group: Caffeine therapy for apnea of prematurity. N Engl J Med 2006;354:2112-2121.

\$6 Doyle LW, Cheong J, Hunt RW, Lee KJ, Thompson DK, Davis PG, Rees S, Anderson PJ, Inder TE: Caffeine and brain development in very preterm infants. Ann Neurol 2010;68: 734-742.

57 Schmidt B, Roberts RS, Davis P, Doyle LW, Barrington KJ, Ohlsson A, Solimano A, Tin W; Caffeine for Apnea of Prematurity Trial Group: Long-term effects of caffeine therapy for apnea of prematurity. N Engl J Med 2007; 357:1893-1902.

58 Schmidt B, Anderson PJ, Doyle LW, Dewey D, Grunau RE, Asztalos EV, Davis PG, Tin W, Moddemann D, Solimano A, Ohlsson A, Barrington KJ, Roberts RS; Caffeine for Apnea of Prematurity (CAP) Trial Investigators: Survival without disability to age 5 years after neonatal caffeine therapy for apnea of prematurity. JAMA 2012;307:275-282.

59 Gray PH, Flenady VJ, Charles BG, Steer PA; Caffeine Collaborative Study Group: Caffeine citrate for very preterm infants: effects on development, temperament and behaviour. J Paediatr Child Health 2011;47:167-172.

60 Doherty GH: Nitric oxide in neurodegeneration: potential benefits of non-steroidal antiinflammatories. Neurosci Bull 2011;27:366382.

61 Donohue PK, Gilmore MM, Cristofalo E, Wilson RF, Weiner JZ, Lau BD, Robinson KA, Allen MC: Inhaled nitric oxide in preterm infants: a systematic review. Pediatrics 2011; 127:e414-e422.

62 Charriaut-Marlangue C, Bonnin P, Pham H, Loron G, Leger PL, Gressens P, Renolleau S, Baud O: Nitric oxide signaling in the brain: a new target for inhaled nitric oxide? Ann Neurol 2013;73:442-448.

63 Pham H, Vottier G, Pansiot J, Dalous J, Gallego J, Gressens P, Duong-Quy S, Dinh-Xuan AT, Mercier JC, Biran V, Charriaut-Marlangue C, Baud O: Inhaled NO protects cerebral white matter in neonatal rats with combined brain and lung injury. Am J Respir Crit Care Med 2012;185:897-899.
Neonatal Treatments and the Developing Brain
Neonatology 2014;106:163-172 DOI: $10.1159 / 000363492$ 
64 Cheung PY, Salas E, Etches PC, Phillipos E, Schulz R, Radomski MW: Inhaled nitric oxide and inhibition of platelet aggregation in critically ill neonates. Lancet 1998;351:11811182.

-65 Schreiber MD, Gin-Mestan K, Marks JD, Huo D, Lee G, Srisuparp P: Inhaled nitric oxide in premature infants with the respiratory distress syndrome. N Engl J Med 2003;349:20992107.

66 Kinsella JP, Cutter GR, Walsh WF, Gerstmann DR, Bose CL, Hart C, Sekar KC, Auten RL, Bhutani VK, Gerdes JS, George TN, Southgate WM, Carriedo H, Couser RJ, Mammel MC, Hall DC, Pappagallo M, Sardesai S, Strain JD, Baier M, Abman SH: Early inhaled nitric oxide therapy in premature newborns with respiratory failure. $\mathrm{N}$ Engl J Med 2006;355:354-364.

-67 Mestan KK, Marks JD, Hecox K, Huo D, Schreiber MD: Neurodevelopmental outcomes of premature infants treated with inhaled nitric oxide. N Engl J Med 2005;353: 23-32.

68 Juul S, Felderhoff-Mueser U: Epo and other hematopoietic factors. Semin Fetal Neonatal Med 2007;12:250-258.

69 Newton NR, Leonard CH, Piecuch RE, Phibbs RH: Neurodevelopmental outcome of prematurely born children treated with recombinant human erythropoietin in infancy. J Perinatol 1999;19:403-406.

-70 Ohls RK, Ehrenkranz RA, Das A, Dusick AM, Yolton K, Romano E, Delaney-Black V, Papile LA, Simon NP, Steichen JJ, Lee KG; National Institute of Child Health and Human Development Neonatal Research Network: Neurodevelopmental outcome and growth at 18-22 months' corrected age in extremely low birth weight infants treated with early erythropoietin and iron. Pediatrics 2004;114:1287-1291.

-71 Bierer R, Peceny MC, Hartenberger CH, Ohls RK: Erythropoietin concentrations and neurodevelopmental outcome in preterm infants. Pediatrics 2006;118:e635-e640.

-72 Neubauer AP, Voss W, Wachtendorf M, Jungmann T: Erythropoietin improves neurodevelopmental outcome of extremely preterm infants. Ann Neurol 2010;67:657-666.

73 Fauchère JC, Dame C, Vonthein R, Koller B, Arri S, Wolf M, Bucher HU: An approach to using recombinant erythropoietin for neuroprotection in very preterm infants. Pediatrics 2008; 122:375-382.

74 Juul SE, McPherson RJ, Bauer LA, Ledbetter KJ, Gleason CA, Mayock DE: A phase I/II trial of high-dose erythropoietin in extremely low birth weight infants: pharmacokinetics and safety. Pediatrics 2008;122:383-391.

75 McAdams RM, McPherson RJ, Mayock DE, Juul SE: Outcomes of extremely low birth weight infants given early high-dose erythropoietin. J Perinatol 2013;33:226-230.
76 Miller SM: Iron supplementation in premature infants using the zinc protoporphyrin to heme ratio: short- and long-term outcomes. J Perinatol 2013;33:712-716.

77 Subhedar NV, Shaw NJ: Dopamine versus dobutamine for hypotensive preterm infants. Cochrane Database Syst Rev 2003;3: CD001242.

78 Osborn DA, Evans N: Early volume expansion for prevention of morbidity and mortality in very preterm infants. Cochrane Database Syst Rev 2004;2:CD002055.

79 Osborn DA, Paradisis M, Evans N: The effect of inotropes on morbidity and mortality in preterm infants with low systemic or organ blood flow. Cochrane Database Syst Rev 2007; 1:CD005090.

80 Osborn DA, Evans N, Kluckow M: Randomized trial of dobutamine versus dopamine in preterm infants with low systemic blood flow. J Pediatr 2002;140:183-191.

81 Sassano-Higgins S, Friedlich P, Seri I: A metaanalysis of dopamine use in hypotensive preterm infants: blood pressure and cerebral hemodynamics. J Perinatol 2011;31:647-655.

82 Batton B, Li L, Newman NS, Das A, Watterberg KL, Yoder BA, Faix RG, Laughon MM, Stoll BJ, Van Meurs KP, Carlo WA, Poindexter BB, Bell EF, Sánchez PJ, Ehrenkranz RA, Goldberg RN, Laptook AR, Kennedy KA, Frantz ID 3rd, Shankaran S, Schibler K, Higgins RD, Walsh MC; Eunice Kennedy Shriver National Institute of Child Health and $\mathrm{Hu}$ man Development Neonatal Research Network: Use of antihypotensive therapies in extremely preterm infants. Pediatrics 2013; 131:e1865-e1873.

83 Dempsey EM, Barrington KJ: Treating hypotension in the preterm infant: when and with what: a critical and systematic review. J Perinatol 2007;27:469-478.

84 Anand KJ, Sippell WG, Aynsley-Green A: Randomised trial of fentanyl anaesthesia in preterm babies undergoing surgery: effects on the stress response. Lancet 1987;1:243-248.

85 Bellu R, de Waal K, Zanini R: Opioids for neonates receiving mechanical ventilation: a systematic review and meta-analysis. Arch Dis Child Fetal Neonatal Ed 2010;95:F241F251.

-86 Ng E, Taddio A, Ohlsson A: Intravenous midazolam infusion for sedation of infants in the neonatal intensive care unit. Cochrane Database Syst Rev 2012;6:CD002052.

87 Loepke AW, McGowan FX Jr, Soriano SG: CON: The toxic effects of anesthetics in the developing brain: the clinical perspective. Anesth Analg 2008;106:1664-1669.

88 Page GG, Blakely WP, Kim M: The impact of early repeated pain experiences on stress responsiveness and emotionality at maturity in rats. Brain Behav Immun 2005;19:78-87.
89 Durrmeyer X, Vutskits L, Anand KJ, Rimensberger PC: Use of analgesic and sedative drugs in the NICU: integrating clinical trials and laboratory data. Pediatr Res 2010;67:117-127.

90 Stevens B, Yamada J, Lee GY, Ohlsson A: Sucrose for analgesia in newborn infants undergoing painful procedures. Cochrane Database Syst Rev 2013;1:CD001069.

91 Stevens B, Yamada J, Beyene J, Gibbins S, Petryshen P, Stinson J, Narciso J: Consistent management of repeated procedural pain with sucrose in preterm neonates: is it effective and safe for repeated use over time? Clin J Pain 2005;21:543-548.

92 MacGregor R, Evans D, Sugden D, Gaussen T, Levene M: Outcome at 5-6 years of prematurely born children who received morphine as neonates. Arch Dis Child Fetal Neonatal Ed 1998;79:F40-F43.

93 Rozé JC, Denizot S, Carbajal R, Ancel PY, Kaminski M, Arnaud C, Truffert P, Marret S, Matis J, Thiriez G, Cambonie G, André M, Larroque B, Bréart G: Prolonged sedation and/or analgesia and 5-year neurodevelopment outcome in very preterm infants: results from the EPIPAGE cohort. Arch Pediatr Adolesc Med 2008;162:728-733.

94 De Graaf J, van Lingen RA, Simons SH, Anand KJ, Duivenvoorden HJ, Weisglas-Kuperus N, Roofthooft DW, Groot Jebbink LJ, Veenstra RR, Tibboel D, van Dijk M: Longterm effects of routine morphine infusion in mechanically ventilated neonates on children's functioning: five-year follow-up of a randomized controlled trial. Pain 2011;152: 1391-1397.

95 Ferguson SA, Ward WL, Paule MG, Hall RW, Anand KJ: A pilot study of preemptive morphine analgesia in preterm neonates: effects on head circumference, social behavior, and response latencies in early childhood. Neurotoxicol Teratol 2012;34:47-55.

96 Simons SH, van Dijk M, van Lingen RA, Roofthooft D, Duivenvoorden HJ, Jongeneel N, Bunkers C, Smink E, Anand KJ, van den Anker JN, Tibboel D: Routine morphine infusion in preterm newborns who received ventilatory support: a randomized controlled trial. JAMA 2003;290:2419-2427.

-97 Anand KJ, Hall RW, Desai N, Shephard B, Bergqvist LL, Young TE, Boyle EM, Carbajal R, Bhutani VK, Moore MB, Kronsberg SS, Barton BA; NEOPAIN Trial Investigators Group: Effects of morphine analgesia in ventilated preterm neonates: primary outcomes from the NEOPAIN randomised trial. Lancet 2004;363:1673-1682.

-98 Grunau RE, Whitfield MF, Petrie-Thomas J, Synnes AR, Cepeda IL, Keidar A, Rogers M, Mackay M, Hubber-Richard P, Johannesen $D$ : Neonatal pain, parenting stress and interaction, in relation to cognitive and motor development at 8 and 18 months in preterm infants. Pain 2009;143:138-146. 